https://doi.org/10.18485/kud_kiaz.2019.ch19

\author{
Lala Madžidova \\ doktor filoloških nauka, docent \\ Azerbejdžanski univerzitet jezika
}

\title{
PROCES FORMIRANJA NOVOG ŽANRA U AZERBEJDŽANKOJ KNJIŽEVNOSTI
}

\begin{abstract}
SUMMARY
This work is a description of a detective fiction in Azerbaijan, which is one of the most productive branches of modern world literature. The world's detective literature has made a great contribution to the theory of literature, but in Azerbaijan it acquires new outlines and brings many new and interesting changes. This work depicts a detective fiction through work of Chingiz Abdullayev. In the essence of the criminal plot he puts not only an interesting psychological game, but also real human suffering, the depth of the human soul, thanks to which the detective novel, like a new genre, opens the way to the great Azerbaijani literature. He emphasizes the idea that there is no need to interfere people, whose waste are bandits, in the "national mafia", and that there are no bad people. Today, this writer is one of the most famous authors of detective novels on the world stage, since he basically combined political events with a detective investigation.
\end{abstract}

Key words: Detective genre, Chingiz Abdullayev, psychological game, Azerbaijani literature.

Detektivski žanr predstavlja jednu od produktivnijih grana savremene svetske književnosti. Književni velikani, koji stvaraju dela u detektivskog žanru, prikazuju kriminalističke događaje, poput ubistava, akte terora, pohlepu vlasti i bogatstva i druge socijalne nesreće, kao jedan od vodećih problema 
savremenog društva. ${ }^{1} \mathrm{~S}$ druge strane, trude se da predstave čitaocu žestoku ljudsku borbu sa tim pojavama, koje dostojno izvršavaju svoje obaveze. ${ }^{2}$ Kao što je poznato, ove ili druge karakteristike detektivskog žanra iskazane su još na drevnim istočnjačkim književnim spomenicima - u „Avesti“, u bajkama „Hiljadu i jedna noćc", u različitim formama narodnih običaja i legendi. A u savremenom shvatanju detektivska književnost nastala je 40-ih godina XIX veka u Americi. Istorijski nastanak detektivskog žanra uslovljen je socijalno-moralnim uslovima i idejno-estetskim korenima, čije istraživanje ima naučno-teorijsko značenje ${ }^{3}$.

Svetska detektivska književnost dala je veliki doprinos teoriji književnosti, proširivši njene granice i mogućnosti. Detektivski žanr u azerbejdžanskoj književnosti doneo je mnogo novih i zanimljivih promena. Žanr se obnovio, razvio i dao nove oblike.

Prateći genezu i razvoj detektivskog žanra u Azerbejdžanu, može se reći, da on u svetskoj književnosti ima čvrste korene koji su dali mogućnost za razvoj žanra u svim njegovim oblicima. Azerbejdžanska detektivska književnost vodi poreklo od mitova, dastana (priča), dela Nizami Gjandževi, u kojima preovladava tematika pravičnosti carskog i božijeg suda.

Azerbejdžansku detektivsku književnost moguće je podeliti na tri osnovna detektivska žanra, koji su se formirali u azerbejdžanskoj književnosti i počeli da odražavaju suštinu detektivskog i kriminalističkog dela. Njegova svrsishodnost, aktuelnost, kao i kompoziciona struktura je policijski detektivski roman, politički detektivski roman, špijunski detektivski roman (detektiv).

Detektivski žanr u Azerbejdžanu tokom poslednje decenije uživa stalnu pažnju čitalaca: štampaju se veliki tiraži odgovarajućih dela (detektivska, kriminalistička i špijunska),

1 Vulis A.Z. Poetika detektiva // Novi svet, 1978, br. 1, str. 4

2 Ramsey G.C. Agatha Christie. Mistress of Mystery. New York: Dodd, Mead \& Company, 1967, str. 30

3 B.Aznur. Avesta. 1995, str. 34 
kako u prevodu, tako i u originalu azerbejdžanskih autora. Detektiv čitaju praktično svi, i ta univerzalnost po opsegu čitalačke auditorije čini ga nepromenljivim ideološkim oružjem protiv zla i nasilja ${ }^{4}$.

Azerbejdžanski detektivski žanr, za razliku od svetskog, karakteriše realnije osvetljavanje kriminalističkog sveta. Utemeljivač špijunskog žanra i policijskih detektiva u Azerbejdžanu postao je Džamšid Amirov 50-ih, 60-ih godina. Sledeća važna vrsta detektivskog žanra u azerbejdžanskoj književnosti, koja uživa veliki uspeh ne samo u republici, već i u inostranstvu je ,,politički detektiv“". $\mathrm{S}$ azerbejdžanskoj prozi Džingiz Abdulajev nastupa kao utemeljivač političkog detektiva, koji je zasnovan na realnim činjenicama i događajima. Za razliku od ,policijskog detektiva“, u ,političkom detektivu“ razmatraju se globalniji opšte ljudski problemi, ali glavna i osnovna tematika, kao i u drugim oblicima detektivske književnosti, ostaje zločin i njegova istraga. U osnovi ,ppolitičkog detektiva“" oslikani su realni istorijski i politički događaji. Zločini imaju globalni karakter velikih razmera, za razliku od „policijskog detektiva“, gde zločini imaju privatan karakter: tu je i biznis sa narkoticima, i politički prevrat, i političke afere, ratni događaji i dr. Politički detektiv se smatra polu dokumentarnom prozom ${ }^{6}$.

Čingiz Abdulajev je rođen u Bakuu 1959. godine. Stekao je tri visoka obrazovanja, govori šest stranih jezika. U periodu 1982-1983. završavao je Viši kurs KGB Sovjetskog Saveza. Radio je u Ministarstvu odbrane, izvršavao zadatke $\mathrm{u}$ inostranstvu kao deo specijalne jedinice posebne namene, radio je u Poljskoj, Nemačkoj, Belgiji, Angoli, Rumuniji i

4 Oliyeva N. Detektiv janr Azarbaycan yeni nasri kontekstinda // Elmi araşdırmalar, 2002, br. 1-2, str. 124-126

5 Bavin S. Predgovor/ Inostrani detektivski roman HH veka. M.: 1991, str. 10

6 Doktor filoloških nauka Medžidova L., Proces formiranja detektivskog žanra u engleskoj književnosti, Doktorska disertacija, Baku, 2008 
Avganistanu. Major u ostavci, nosilac niza vladinih nagrada, doktor pravnih nauka. Narodni pisac i član Saveta starešina Udruženja književnika Azerbejdžana, član Upravnog odbora Međunarodnog Fonda za saradnju i partnerstvo Crnog i Kaspijskog mora. Profesor na katedri za kriminalističko pravo Azerbejdžanskog međunarodnog Univerziteta, član Komisije za dodelu državnih nagrada Republike Azerbejdžan iz oblasti nauke, kulture i književnosti. Od jula 2011. godine član je Koordinacionog Saveta Azerbejdžanaca u svetu.

Od oktobra 2014. godine - počasni doktor Univerziteta za bibliotekarstvo i informacione tehnologije (Sofija, Bugarska).

Dobitnik je nagrade «Grand-master» (Letonija, 2001), «HUMAY» (Azerbejdžan, 2004), nagrade Udruženja novinara Azerbejdžana «Zlatno pero» (Azerbejdžan, 2004), «Čast i dostojanstvo» (Rusija, 2004), «Opera Omnia» Tjudor Argezi (Rumunija, 2011), «Platinsko pero» (Azerbejdžan, 2013).

Dodeljena mu je nagrada nemačkih knjižara ,Za doprinos razvoju evropskog romana" (2004). Počasni je građanin grada Trgu-Kerbunešti, Rumunija (2011). (Bez obzira na to, što su mu 1986. godine zabranili ulazak u Rumuniju, i što je tokom osamnaest godina bio persona non-grata u toj zemlji).

Kako bismo shvatili svrsishodnost dela Č. Abudulajeva, njegov odnos prema kriminalu i mafiji, ukratko možemo da izrazimo autorovu ideju odlomkom - predgovorom iz knjige „Zakon podlaca“ njegovim rečima: „Želeo bih da skrenem pažnju čitaocima na jednu veoma važnu okolnost. Ne treba mešati „nacionalnu mafiju“ i narod, čiji su otpaci ti banditi. Ne postoje loši narodi, to je jednostavna istina, koji još mnogi nisu usvojili. Ako je potrebno, oni umeju da se dogovore. Pamtite ovo svi, ostajte ljudi, koji poštuju čoveka zbog njegovog rada, uma, čestitosti, a narod - zbog njegove istorije, kulture, tradicije, a sebe - zbog umeća da poštujete druge, ne spuštajući se na nivo primitivnog nacionalizma. Na kraju krajeva, tako je teško - biti Čovek“".

7 Č. Abudulajev, „Stil podlaca“, , Moskva, Eksmo. 1998, str. 11 
Čingiz Abdulajev je autor 194 romana i novela, pripovetki, preko 440 publicističkih članaka, čiji je ukupan tiraž nadmašio 25 miliona primeraka na 28 jezika. Njegove knjige rasprodaju se za tren oka, a on sam, kao građanin Azerbejdžana, prema tvrđenjima „Književnom pregleda“, ulazi u prvih deset najčitanijih ruskih pisaca. Njegovo ime kao najčitanijeg pisca na ruskom jeziku uneto je u Ginisovu knjigu rekorda. Po njegovim delima napisano je 60 filmskih scenarija. Po delima i scenarijima ovog autora snimljeno je sedam filmova i dve serije. Početak njegovog književnog stvaralaštva utemeljili su istorijski roman i nekoliko lirskih priča. Prvi roman akcionog žanra „Plavi anđeli“, KGB je tri godine branio da se štampa, zbog navodno skrivenih informacija u njemu. Autorova novina se ogleda u tome što je on, još tokom života političkih rukovodioca, pisao o njima, njihovim greškama i porocima. Gorbačov, Jeljcin, Putin, često su mnogi od njih prekriveni drugim imenima, ali ih je lako prepoznati po njihovim procenama, delima, opisima i mnogim drugim karakterističnim crtama. Njegova dela su poučna i nose kosmopolitski karakter ${ }^{8}$.

Procesi koji su se odvijali u raznim zemljama, između ostalog u SAD, Rusiji, Azerbejdžanu, u određenoj meri vezani su za socijalno-istorijske uslove, promene, razvoj društvenih odnosa i preobražaj - napredak civilizacija u društvu, i svakako, umetničke potrage u književnosti.

Duboke promene u privrednim događanjima i socijalnom životu zemalja sveta izazvali su ništa manje promene u ponašanju, u formiranju morala kod ljudi.

Čingiz Abdulajev je u svetskoj detektivskoj književnosti istaknut kao jedan od najboljih autora detektivskog žanra.

Č. Abdulajev - autor mnogih romana i pripovetki, napisanih u žanru "političkog detektiva" - "Plavi anđeli", "Lov na čoveka", "Stil podlaca", "Tri boje krvi", "Balkanski sindrom", "Oponenti Evrope" i mnogih drugih". U njegovim delima prisutna je i avganistanska tematika "Otići i ne vratiti

8 http://www.livelib.ru/author/7903

9 http://www.libok.net/writer/5186/abdullaev_chingiz_akifovich 
se", on dodiruje temu raspada bivšeg Sovjetskog Saveza "U očekivanju Apokalipse”. Glavni i važan junak njegovih detektiva postaje profesionalni obaveštajac "Drongo", pripadnik starih i strogih poredaka. „Drongo“ je kolektivni odraz, jaka i hrabra priroda, u njemu su oslikane crte karaktera i razmišljanja samog autora. Junak se pojavljuje pod raznim imenima. Drongo je simbolično ime, to je ptica iz jugo-istočne Azije, koja označava hrabrost i veru u bolju budućnost. Obaveštajac je kod pisca protivrečna priroda: njegov junak „Drongo“ donosi korist mnogim ljudima: on učestvuje u pronalaženju i uništavanju laboratorije, koja proizvodi drogu, rasvetljava mehanizme korupcije, izdaje i mnoge druge stvari, i istovremeno se oseća nemoćno i bespomoćno kada vidi raspad jedne od najvećih država i, samim tim, njegove političke ustanove - obaveštajnog aparata, koji je nekada nosio ime KGB. Stari je poredak, po mišljenju junaka, bio dobar, ali su greške, trulež, ludilo komunističkog poretka dovele su rušenja imperije i pojave novih poteškoća, nesreća u stvaranju nove, zasad još neodređene države.

On stremi ka cilju, veran je svojim prijateljima, može da ostane to što jeste, mada ume da bude i sarkastičan, voli da se pravi pametan, njegovi postupci nikada nisu neprecizni, kao i u „dobrom romanu“, on voli ponekad da primeni silu (pesnice ili pištolj), kako bi pobedio zlo, veran je svojim idealima i on je za poredak.

Junaci-obaveštajci u političkom detektivu, kako u svetskoj, tako i u azerbejdžanskoj književnosti, slični su u smislu svrsishodnosti, smelosti duha i razuma, ali svaki junak ima određenu karakternu crnu, svaki postupa drugačije, postižući ciljeve na svoj način.

Politički detektiv u delima Č. Abdulajeva karakteriše aktualnost, zaokruženost, osmišljeni i dovršeni žanr; autor u svojim delima koristi citate genijalnih mislilaca i predstavnika svetske umetnosti, književnosti i kulture čovečanstva, u kojima se odražava suština dela, njegova svrsishodnost, dela se oslanjaju na realne istorijske i političke događaje, razotkriva se psihologija ljudske duše. 


\section{REZIME}

Rezimirajući gore navedeno, možemo istaći da azerbejdžanski detektivski roman karakteriše krajnja oštrina sukoba, zanimljiv siže, duboko istraživanje životnih problema, gde je sposobni zločinac, bez obzira na snalažljivost, neminovno osuđen na poraz, a manje talentovani islednik, isto tako fatalno, na pobedu.

U svojim delima autor je prikazao sve licemerje, prljavštinu, podmitljivost, pohlepu, korumpiranost zločinačkog sveta, koji dopiru do samog vrha vlasti, pod nazivom mafija. Cilj mafije je: prodati i izdati sve zbog sopstvene dobrobiti.

U osnovi kriminalističke priče nije samo zanimljiva psihološka igra, već i realna ljudska patnja, dubina ljudske duše, zahvaljujući čemu se detektivskom romanu, kao novom žanru, otvara put u veliku azerbejdžansku književnost.

Danas je ovaj pisac jedan od poznatijih autora detektivskih romana u svetskoj areni, pošto je u osnovi svojih dela ujedinio političke događaje sa detektivskom istragom. Upravo zbog toga želeli bismo da se i srpski čitaoci, takođe, upoznaju sa piščevim stvaralaštvom. Sa tim ciljem, u najskorije vreme će Kulturni centar Azerbejdžana u Beogradu prevesti neka dela Čingiza Abdulajeva na srpski jezik i predstaviti ih srpskim čitaocima.

\section{Literatura:}

Vulis A.Z. Poetika detektiva // Novi svet, 1978, br. 1

Rodell M.F. Writing Detective and Mystery Fiction. Boston, 1945

Ramsey G.C. Agatha Christie. Mistress of Mystery. New York: Dodd, Mead \& Company, 1967

Bavin S. Predgovor/ Inostrani detektivski roman HH veka. M.: 1991

Oliyeva N. Detektiv janr Azarbaycan yeni nasri kontekstinda // Elmi araşdırmalar, 2002, br. 1-2

Medžidova L., Proces formiranja detektivskog žanra u engleskoj književnosti, Doktorska disertacija, Baku, 2008

B.Aznur. Avesta. 1995 
Čingiz Abdulajev. „Plavi anđeli“. Roman. B-Jaziči, Baku , 1988, Čingiz Abdulajev „Lov na čoveka“. Roman. B-Jaziči. Baku, 1992, Čingiz Abdulajev, Stil podlaca, Roman, Moskva, Eksmo. 1998. http://www.livelib.ru/author/7903 http://www.libok.net/writer/5186/abdullaev_chingiz_akifovich

\section{Bibliografija:}

Adamov A., Moj omiljenižanr - detektivski roman, Moskva, 1980.

Adamov A., Inostrani detektivski roman, Moskva, 1966 № 10

Bavin S., Inostrani detektivski roman XX veka, Moskva, 1991

Juridič M., Antologija svetskog detektivskog romana, tom 6: Moskva, 1995

Mip-Bagirova Samira., Detektivski žanr u svetskoj književnosti, Doktorska disertacija, Baku, 1998

Semjonov J, Moj omiljeni žanr-detektivski roman, «Sovjetska Litva». 1987

Čingiz Abdulajev. Savest podlaca: Roman. — Rostov-na-Donu: ProfPress, 1995

Čingiz Abdulajev. Krug podlaca: Trilogija. // Zakon podlaca; Kredo podlaca; Savest podlaca: Romani. — Rostov-na-Donu - Harkov: ProfPress; EvroEkspress, 1996

Čingiz Abdulajev. Simboli raspada: Roman. — Moskva: Eksmo, 1998

Čingiz Abdulajev. Put rata: Roman. — Moskva: Eksmo, 2001

Čingiz Abdulajev. Poriv za vlast, Subjekat vlasti: Roman. Moskva: AST, 2005

Čingiz Abdulajev. Vraćanje grehova: Roman. — Moskva: Eksmo, 2008 2009

Čingiz Abdulajev. Festival za južni grad: Roman. - Moskva: Eksmo,

Čingiz Abdulajev. Oponenti Evrope : Roman. — Moskva: Eksmo, 2013

Čingiz Abdulajev. Zlatno pravilo etike: Roman. — Moskva: Eksmo, 2014

\section{РЕЗЮМЕ}

Эта работа является описанием детективного жанра в Азербайджане, который является одной из наиболее продуктивных отраслей современной мировой литературы. Мировая детективная литература внесла большой вклад в теорию литературы, но в Азербайджане она приобретает новые очертания и приносит много новых и интересных изменений. Эта работа изображает детективный жанр путем творчества Чингиза Абдуллаева. Он в суть крими- 
нального сюжета ставит не только интересную психологическую игру, но и реальные человеческие страдания, глубину человеческой души, благодаря которой детективный роман, как новый жанр, открывает путь в великую азербайджанскую литературу. Он подчеркивает мысль о том, что нет необходимости вмешивать в «национальную мафию» людей, чьи отходы - бандиты, и что нет плохих людей. Сегодня этот писатель является одним из самых известных авторов детективных романов на мировой арене, поскольку он в основном объединил политические события с детективным расследованием.

Ключевые слова: Детективный жанр, Чингиз Абдуллаев, психологическая игра, азербайджанская литературу. 